
\section{VISUAL AND AUDITORY EVOKED POTENTIALS IN}

R. Korinthenberg, K. Ullrich, F. Füllenkemper Pediatric University Clinics D-6800 Mannheim and D-4400 Münster, Fed. Rep. Germany

Evoked potential testing was done in 34 adolescent patients with hyperphenylalaninemia (21 type 1, 8 type 2, 4 type 3, 1 DHPR deficiency) and in 35 control persons. In all but 4 of the type 1 and 2 patients the dietary treatment had been started during the first 12 weeks of life. In 22 the diet had been terminated at the age of $10.1+1.6$ years (range $6-13$ years). 8 patients were still on diet at the time of this investigation.

In the pattern reversal VEP a prolongation of the latency of wave P100 was found $(104.3 \pm 6.2 \mathrm{~ms}$ vs. $99.3 \pm 3.4 \mathrm{~ms}, \mathrm{p}<0.001)$. This prolongation correlated significantly with the quality of diet during the first 10 years of life. Controling for the quality of diet no influence of the age at which the diet was terminated was demonstrated. There were no correlations between the VEP findings and the Phe concentration at later ages.

Click-evoked BAEPs were normal with regard to the latency and shape of waves I through $V$. The only difference between patients and control persons was an increase of the interear difference of the interwave lateny I-V.
EFFECTS OF PARTIAL PLASMA EXCLANGE TRANSFUSION (PPET) ON CEREBRAL BLOOD FLOW VELOCIIY (CBFV) IN POLYCYTHAEMIC NEWBOFN INFANIS.

Wiel J. Maertzdorf, Dick W. Slaaf*, Geert J. Tangelder**, Carlos E. Blanco. (Spon. by Albert Okken.) Univ. of Limburg, Depts. of

Neonatology, Biofysics* and Fysiology**, Maastricht, The Netherlands. In 37 newbom infants with polycythaemia (with or without clinical symptoms) we performed a PPET. CBFV was measured before, 3, 12 and 24 hours after PPET. In a matched control gnoup ( $N=15$ ) CBFV was measured 6,12 , and 24 hours after birth. CBFV was reconded with a bidinectional $5 \mathrm{mtz}$ continuous wave velocineter. Recondings were made from the anterior cerebral and left mid cerebral arteries. The study group included 14 term infants, 11 preterm infants and 12 snall for date infants. The peripheral venous Hct decreased fran $72.5+2.7 \%$ $(\bar{x} \pm \mathrm{SD})$ to $60.1 \pm 4.2 \%$ after PPET. Heart rate and blood pressure did not chiange significantly. Peak systolic flow velocity (PSFV), peak diastolic flow velocity (PDFV) and mean flow (AUTC) increased significantly $(\mathrm{P}<0.001$ ) at 3 hours after PPET. The PI (PSFV-PDFV/PSFV) did not change significantly $(0.1<\mathrm{P}<0.5)$. CBFV obtained after PPET did not differ from CBFV in the control group and this remained constant at 12 and 24 hours thereafter. When analysing the changes in CBFV after PPET we observed comparable changes of flow parameters in the 3 subgraups of infants within the study group. We concluded that lowering the Hct by PPET in polycythaemic newborm infants nomalises the CBFV after 3 hours and this remains constant up to 24 hours. This could help to clarify indications to PPET in polycy thaenic newborns.
14 MUTUAL CORRECTION OF ${ }^{14} \mathrm{C}$-GALACTOSE MACROMOLECULAR INCORPORATION AND SECRETION BY GALACTOKINASE (GK) AND GALACTOSE-1.PHOSPHATE URIDYLTRANSFERASE (UDPT-) DEF-1CIENT FIBROBLASTS IN CULTURE

Jakob von Känel ${ }^{\circ}$ Beat Steinmann* Ricco Gitzelmann* and Ulrich $N$ Wiesmann ${ }^{\circ}$, Univ. of Bern ${ }^{\circ}$ and Zurich*, Depts of Pediatrics.

${ }^{14} \mathrm{C}$-galactose $\left({ }^{14} \mathrm{C}\right.$-Gal) or ${ }^{14} \mathrm{C}$-galactosamine $\left({ }^{14} \mathrm{C}\right.$-GalN) and ${ }^{14} \mathrm{C}$ - $\mathrm{N}$-acetylgalactosamine ( $\left.{ }^{14} \mathrm{C}-\mathrm{NACGaIN}\right)$ when added to culture medium were incorporated into cellular and into secreted extracellular macromolecules by normal human fibro blasts. GK- fibroblasts incorporated less than $5 \%$ of both ${ }^{14} \mathrm{C}$-Gal and ${ }^{14} \mathrm{C}$-GalN into cellular and less than $10 \%$ into extracellular macromolecules, while UDPT- fibroblasts incorporated about $25 \%$ into cellular and $10 \%$ into extracellular macromolec ules. ${ }^{14} \mathrm{C}$-NACGaIN was incorporated by GK- and UDPT- cells similarly to normal. Fibroblasts from the two genetic enzyme deficencies, when cocultured to equal parts at high density, mutually compensated the macromolecular ${ }^{14} \mathrm{C}$-Gal incorporation. GK- Cells incorporated ${ }^{14} \mathrm{C}$-galactose-1-phosphate $\left({ }^{14} \mathrm{C}\right.$-Gal-1-P) or UDP- ${ }^{14} \mathrm{C}$ galactose (UDP- ${ }^{14} \mathrm{C}$-Gal) similarly to control fibroblasts. UDPT" cells incorporated ${ }^{14} \mathrm{C}$-Gal-1-P only to $10 \%$ compared to control fibroblasts, while UDP. ${ }^{14} \mathrm{C}$-Gal was incorporated normally.

Conclusion: 1. GaIN and Gal but not NAcGaIN are incorporated into macromolecules by the same enzymes.

2. Restoration of Gal and GalN incorporation by coculture of UDPT- and GK- cells, may be explained by mutual exchange of Gal-1.P or GalN-1-P and their nucleotides by cell cell interaction.
DIFFERENTIALLY TMPAIRED OXIDATYON OF BRANCHEDCHAIN AMINO ACIDS IN MAPLE SYRUP URINE DISEASE (MSUD) FIBROBLASTS

Peter Schadewaldt 1 and Udo Wendel ${ }^{2}$

(spon. by H.-J. Bremer), Inst. Physiol. Chem. II $^{1}$ and Kinderk1inik $\mathrm{C}^{2}$, Univ. of Düsseldorf, FRG Whether the impaired branched-chain 2-oxo acid dehydrogenase (BCOA-DH) activity in MSUD is concurrently or rather differentially reduced against the different 2-oxo acid substradifferentially reduced against the ${ }_{14} \mathrm{ff}$ ferent 2 -oxo acid substrates was assessed by measuring the $\mathrm{CO}_{2}$ release in $90 \mathrm{P}$ min incu-
bations of cultured human skin fibroblasts with $1-{ }^{4} \mathrm{C}-1$ labeled branched-chain L-amino acids 18 BCAA) at $1 \mathrm{mmol} / 1$.

In controls (5 strains), ${ }^{14} \mathrm{CO}_{2}$ was in the order val $>$ ile $\geqslant$ leu $>$ allo-ile and amounted to about $8,6,5$, and $2 \mathrm{nmol} / 90 \mathrm{~min}$ per mg of cell protein. In the MSUD cell lines JA, TE, MO (variants), JK, 14 and $\mathrm{NO}$ (classical), residual BCOA-DH activity (as compared to ${ }^{14} \mathrm{CO}$ release in controls $=100 \%$ ) with val, ile, leu, and allo-ile amounted to about $6,10,7$, and $30 \%$, to 7,8 , 9 , and $35 \%$, to $2,2,4$, and $9 \%$, to $2,3,4,7$ and $20 \%$ and to 2,4 , 9 , and $35 \%$, to $2,2,4$, and $9 \%$, to $2,3,4$, and $20 \%$ and to 2,4 ,
3 , and $37 \%$, respectively. These differences could not be attributed to different BCAA transamination rates.

Apparently, BCOA-DH activity in MSUD cells was differentially impaired against the different substrates tested, though to a varying extent. The observed differences might contribute to the clinical and clinical-chemical heterogeneity iı MSUD. 17 CEREgRal VASODILATATION RESPONSE TO ACETAZOLAMIDE Marianne Thoresen and Andrew Whitelaw Neurophys1ology Dept,Karolinska Inst1tute, Stockholm.

Th1s study investigates the effect of azetazolamide on cerebral blood flow, blood pressure, and $\mathrm{CO} 2$ ellmination. 9 newborn piglets were studied. They were anaesthetised ventilated, paralysed, and arterial and venous catheters were inserted. A fontanelle was surgically created and cerebral blood velocity (CBV) in an intracranial artery measured with a $5 \mathrm{MHz}$ computerised Doppler (V1ngmed SD 100) system held on the fontanelle.

$50 \mathrm{mg} / \mathrm{kg}$ acetazolamide IV produced a large increase in CBV (median $70 \%$, range 38-100\%) with no change in arterial pressure. Within 1 minute of administration of acetazolamide, end-explratory $\mathrm{CO} 2$ started to fall (median fall 45\%) and arterlal. pC02 started to rise (median rise $1.3 \mathrm{kPa}$ ), despite controlled ventilation being unchanged. The vasodilatation response to acetazolamide was lost if the cerebral circulation was already dilated by a high pCO2.

It seems likely that acetazolamide inhibits the transfer of $\mathrm{C} 02$ from brain tissue to bicarbonate within cerebral blood vessels and so allows local butld-up of $\mathrm{CO} 2$ around the cerehral vessels smooth muscle, thus producing cerebral vasodilatation. 18 ACUTE EFFECTS OF ACETAZOLAMIDE IN THE NEWBORN INFANT

Hammersmith Hospital, London, England.

Acetazolamide $1 \mathrm{~s}$ being increasingly used for the treatment of post-haemorrhagic ventricular dilatation. The alms of this study were to determine what effects acetazolande had on cerebral blood flow, intra crantal pressure, and respiration in newborn infants

7 infants were atudied. 6 had post-haemorrhaglc ventricular dilatation and one had external hydrocephalus. They received their first dose of acetazolamide $50 \mathrm{mg} / \mathrm{kg}$ IV at a postnatal age ranging from 2 to 17 weeks. Measurements of mean average cerebral blood velocity ( $C B V$ ) were made from the middle cerebral artery using the duplex Doppler Vingmed CFM 700 system. Intracranial pressure was measured invasively in 5 infants and with a fontanometer in 2 .

CBV increased in all cases by a median of $86 \%$ Maximum increase was reached within 2-15 minutes after slow IV injection. The duration of the effect varied frotn 30 minutes to more than 3.5 hours. Intracrantal pressure increased in 5 infants by a median of $7 \mathrm{~mm} \mathrm{Hg}$ and was unchanged in 2. PCO2 rose by median of $0.2 \mathrm{kPa}$ (range 0.2 to $0.6 \mathrm{kPs}$ ) and then fell as the resplratory rate increased by approximately 10 breaths/minute. 